\title{
A rare fetal umbilical cord complication: 37 week antenatal loss
}

\author{
Banu Öndes, $\mathrm{MD}^{1}$
}

Keywords: Nuchal cord, umbilical cord, pregnancy, true knot in cord

\section{Abstract}

Introduction: Investigation of antenatal fetal loss case due to the umbilical cord wrapping 3 times around the neck of a 37-week fetus and being truly knotted in 2 places in light of the literature.

Case: A 35-year old G:4 P:3 patient applied with the complaint of no movement of the baby for 3 days. Ultrasonography observed fetal biometric measurements in accordance with 37 weeks gestation, $3210 \mathrm{gr}$ weight with normal amount of amniotic fluid. Doppler USG observed an in utero mort fetus with 3 loops of nuchal cord. The placenta was observed on the anterior wall. Examination one week previously did not identify cord around the fetal neck, and biophysical profile was evaluated as 10 points. During cesarean section the cord was found to be fully wrapped around the neck of the fetus 3 times and true knots were found at 2 places in the cord. The total length of the umbilical cord was $125 \mathrm{~cm}$ and a wide and deep mark was left on the fetus' neck.

Discussion: Observed in 1 of 3 pregnancies and generally benign, nuchal cord is a complication that rarely causes antenatal loss.

${ }^{1}$ Clinics of Gynecology and Obstetrics, Üsküdar Anadolu Hastanesi, Istanbul, Turkey

\section{Introduction}

The umbilical cord wrapping around the neck of the fetus is observed in 23-33\% of all pregnancies and is generally benign. ${ }^{1}$ Nuchal cord is the most common of all umbilical cord complications with a $79.1 \%$ rate. $^{2}$ Complications such as true knot in the cord, cord wrapping of the body or extremities, prolapse and rupture are observed less often.

In many pregnancies, despite not causing any adverse perinatal outcome, nuchal cord may sometimes lead to undesirable results. ${ }^{3}$ Nuchal umbilical cord implies a possible fetal risk and could be a reason for intrauterine fetal death. $^{4}$ In $5-18 \%$ of all cord complications, fatal perinatal asphyxia is observed. ${ }^{5}$

This case report evaluates a fetal loss where the cord was wrapped 3 times around the neck and 2 true knots in the cord in a 37 week pregnancy, with no

Please cite this paper as: Öndes B. A rare fetal umbilical cord complication: 37 week antenatal loss. Proc Obstet Gynecol. 2016;6(2): Article 6 [ 7 p.]. Available from: http://ir.uiowa.edu/pog/ Free full text article.

Corresponding author: Banu Öndes, Clinics of Gynecology and Obstetrics, Üsküdar Anadolu Hastanesi, Istanbul, Turkey.drbanuaslan@gmail.com

Financial Disclosure: The author reports no conflict of interest.

Received: 17 June 2016; accepted 28 July 2016; POG in Press, 8 August 2016

Copyright: (c) 2016 Öndes. This is an open-access article distributed under the terms of the Creative Commons Attribution License, which permits unrestricted use, distribution, and reproduction in any medium, provided the original author and source are credited. 
nuchal cord observed during antenatal check-ups.

\section{Case Presentation}

A 35-year old G:4 P:3, with previous one cesarean operation, was 37 weeks pregnant according to last menstrual period. The reason for application was that the baby had not moved for 3 days. The patient's first pregnancy check-up was at 11 weeks, with nuchal thickness (NT) measured as $1 \mathrm{~mm}$ and a combined risk of $<1: 10000$ on dual test with free beta HCG of $30.9 \mathrm{ng} / \mathrm{ml}(0.74$ MoM PAPP-A: $1.11 \mathrm{mIU} / \mathrm{mL} \quad(0.84$ MoM). The anatomy of the fetus was normal. Hemoglobin values were 9.1 $\mathrm{g} / \mathrm{dL}$ so anti-anemics were begun. The patient did not attend regular pregnancy check-ups. The patient came for a second check-up at 26 weeks pregnant. Biometric measurements were in accordance with the week of pregnancy, the cord was not identified around the fetus' neck, and the placenta was located anterior. A $75 \mathrm{~g}$ oral glucose tolerance test, full urine tests and hemogram were requested. The patient did not comply. The patient came for 3rd pregnancy check-up at 35 weeks. Blood pressure was $150 / 80 \mathrm{mmHg}$. On ultrasonography the fetus weighed 2729 $\mathrm{g}$ with sufficient amniotic fluid and the cord was not observed around the fetal neck. A nonstress test (NST) was reactive with no contractions; biophysical profile was assessed as 10 points. Protein in urine was negative. The patient was referred to another education and research hospital for blood pressure monitoring. The patient was admitted for 2 days and discharged in good health. Blood pressure monitoring and NST were normal. The patient was called for NST check-up but did not attend. When she applied 10 days later USG measured fetal weight as $3100 \mathrm{~g}$. BP: $120 / 80 \mathrm{mmHg}$, NST reactive, biophysical profile was 10 points. Nuchal cord was not observed. She was called for NST check-up but did not attend. Seven days later the patient applied with the complaint that the baby had not moved in 3 days. USG did not observe fetal heart rate, amniotic fluid was within normal limits and the placenta appeared normal. On 3d USG, 3 loops of the cord were observed around the neck. The patient was taken for cesarean. During the operation a $3210 \mathrm{~g}, 36 \mathrm{~cm}$ head circumference, 50 $\mathrm{cm}$ long female infant was born with nuchal cord and true knot observed in 2 places and 0/0 Apgar score. When the cord was removed deep circular marks were observed on the neck of the fetus and the umbilical cord length was measured as $125 \mathrm{~cm}$. (Figure 1,2,3)

\section{Discussion}

Wrapping of the umbilical cord around the neck of the fetus is observed in 23$33 \%$ of all pregnancies and is generally benign. ${ }^{1}$ This rate is reported as $42.9 \%$ in the 2nd trimester. ${ }^{6}$ Of all umbilical cord complications it is the most common with $79.1 \%$ nuchal cord. If all nuchal cord are examined, 1 loop is observed in $74.6 \%$ while multiple loops are observed at a rate of $25.4 \%$. The 2nd most common cord problem is cord prolapse with a rate of $12.4 \%$. True knots are observed in 3.9\%. These are followed by cord presentation (1.9\%), cord rupture (1.2\%), velamentous insertion (1.2\%) and cord wrapping around the trunk $(0.4 \%){ }^{4}$ A normalcoiled umbilical cord with the support of 
Wharton's jelly is thought to be more resistant to compression, stretch, and torsion. $^{7}$

From the time when the cord length reaches $4 / 5$ of the fetus length, it is reported it may wrap around the neck. ${ }^{8}$
The incidence of 1 loop of cord wrapping the neck is $10.6 \%$, while this rate is determined to be $2.5 \%$ for 2 loops, $0.5 \%$ for 3 loops and $0.1 \%$ for 4 loops. ${ }^{2}$ In our case the cord had wrapped 3 times around the fetus' neck and there were true knots in 2 places.

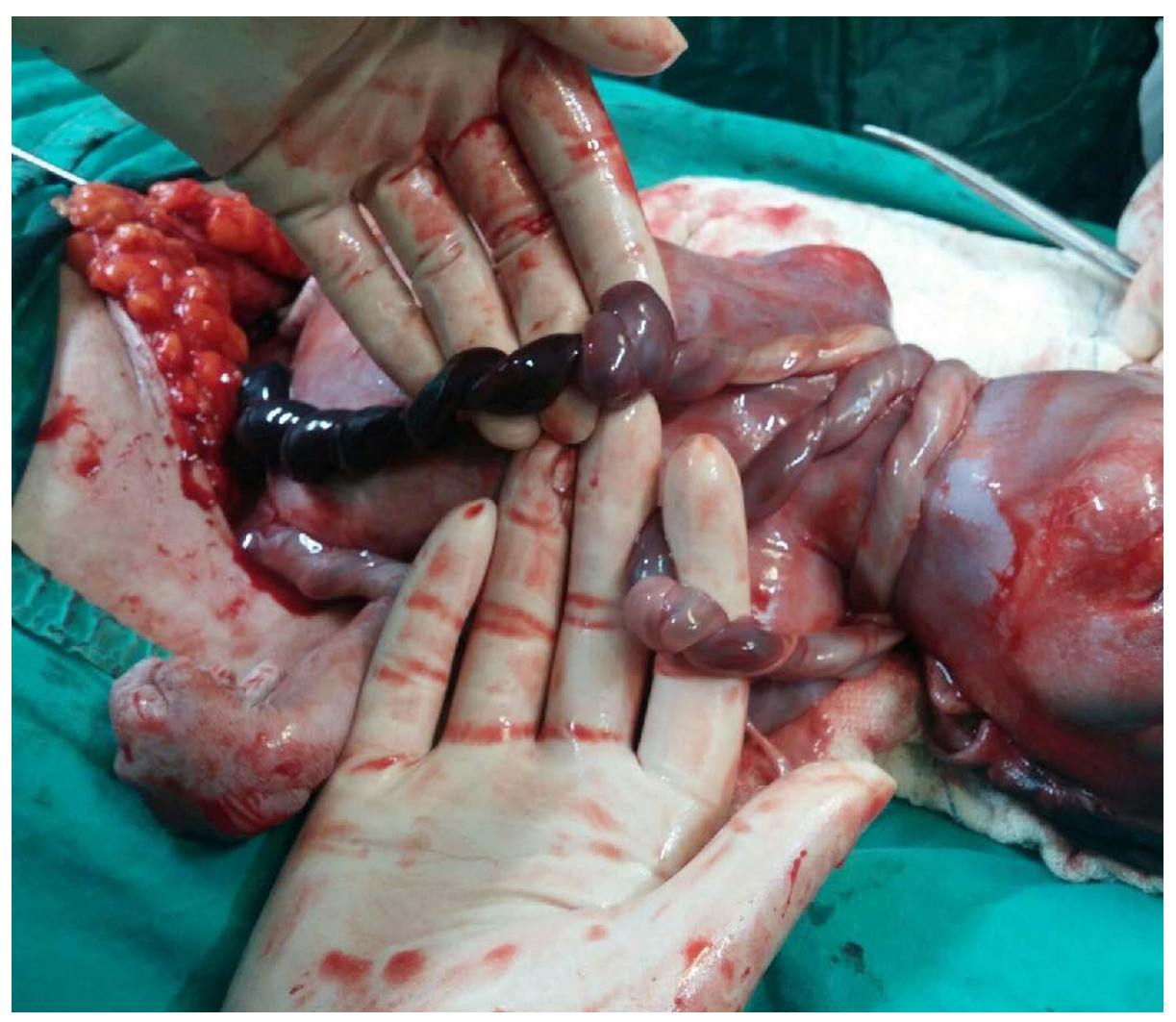

\section{Figure 1}

It is stated that parallel to the increase in the number of loops of the nuchal cord, there is an increase in the incidence of fetal asphyxia. ${ }^{9}$ Nuchal cord is identified as a cause of antepartum and intrapartum variable deceleration and oligohydramnios, along with situations such as fetal distress and acidemia. ${ }^{10}$ Some series have held nuchal cord primarily responsible for bad fetal prognosis and antepartum fetal death. ${ }^{11,12}$ Umbilical cord entanglement around the trunk was associated with a higher risk of low Apgar scores and low umbilical artery $\mathrm{pH}^{13}$

Factors related to nuchal cord include length of the cord, presentation of the fetus, location of the placenta, amount of amniotic fluid, movement of the fetus, 
week of pregnancy, and sex and weight of the fetus. ${ }^{14}$ Nuchal cord is more commonly observed with breech presentation and male fetus. ${ }^{15}$

At birth, the mature cord is about $50-60$ $\mathrm{cm}$ in length and $12 \mathrm{~mm}$ in diameter. A long cord is defined as $>100 \mathrm{~cm}$ and a short cord as $<30 \mathrm{~cm}$. Short and long cord cases had higher incidence of cord complications, increased incidence of operative interference, intrapartum complications, increased fetal heart rate abnormalities and more chances of birth asphyxia. $^{16}$

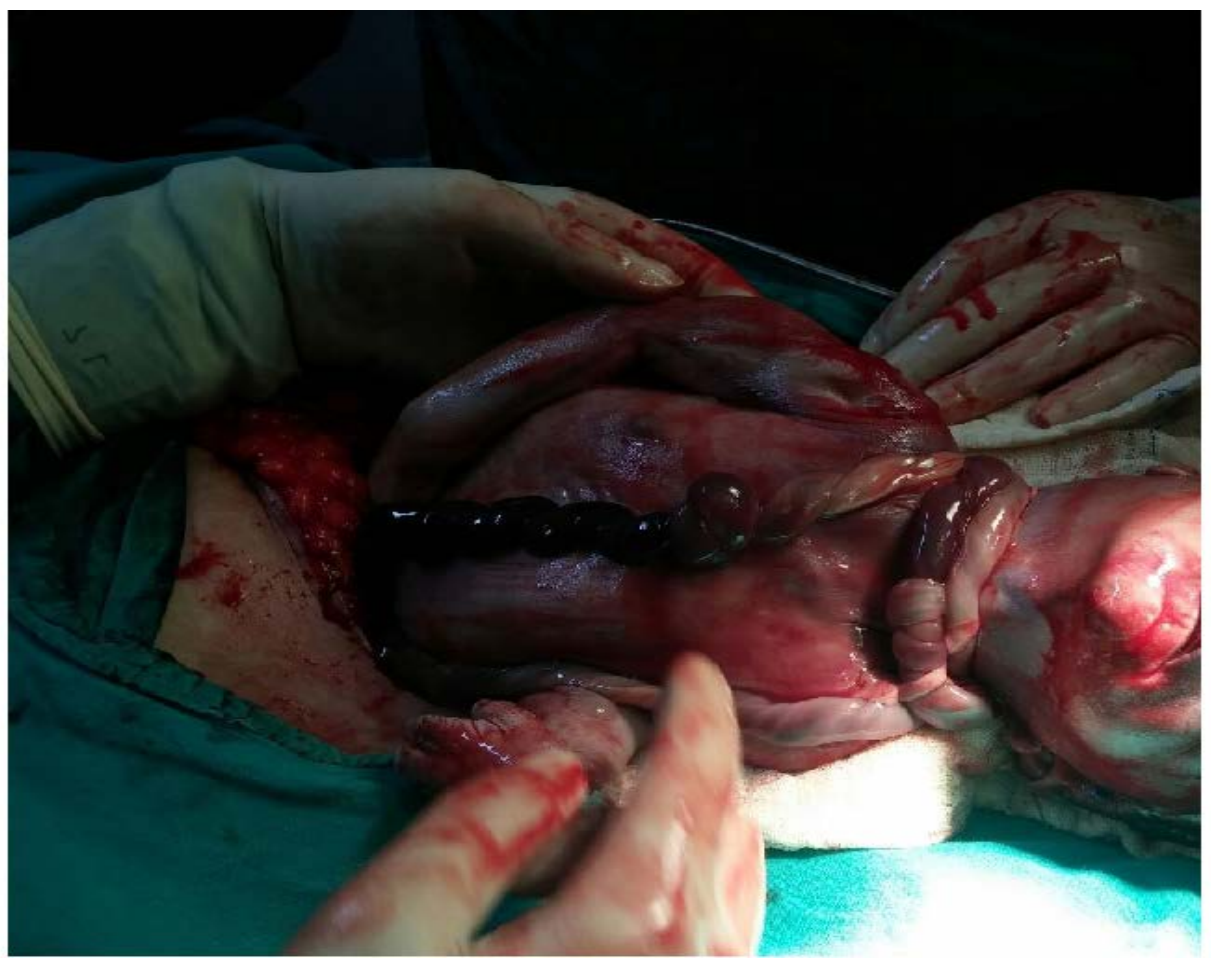

\section{Figure 2}

In our case the cord length was $125 \mathrm{~cm}$, amniotic fluid volume was normal, the fetus was head down and was a girl. It is reported in the literature that the placenta on the anterior wall affects nuchal cord. $^{17}$ In our case, in accordance with the literature; the placenta was located on the anterior wall.

The finding of an entanglement increased significantly from $5.8 \%$ at 20 weeks to $29.0 \%$ at 42 weeks' gestation. ${ }^{18}$ Our case was in the 37 th week and ultrasonography and Doppler USG performed one week previously did not observe nuchal cord.

From the 2nd trimester on, fetal examination with ultrasonography and Doppler ultrasonography can identify nuchal cord. The sensitivity for 
grayscale ultrasonography to identify nuchal cord is $70.3 \%$, with the sensitivity reported as $96.8 \%$ on color Doppler images. ${ }^{19}$ Absence of fetal movements, variable cardiotocograms, abnormal waveforms of umbilical artery and ductus venosus in Doppler studies may be attributed to multiple loops of nuchal cord. ${ }^{7}$

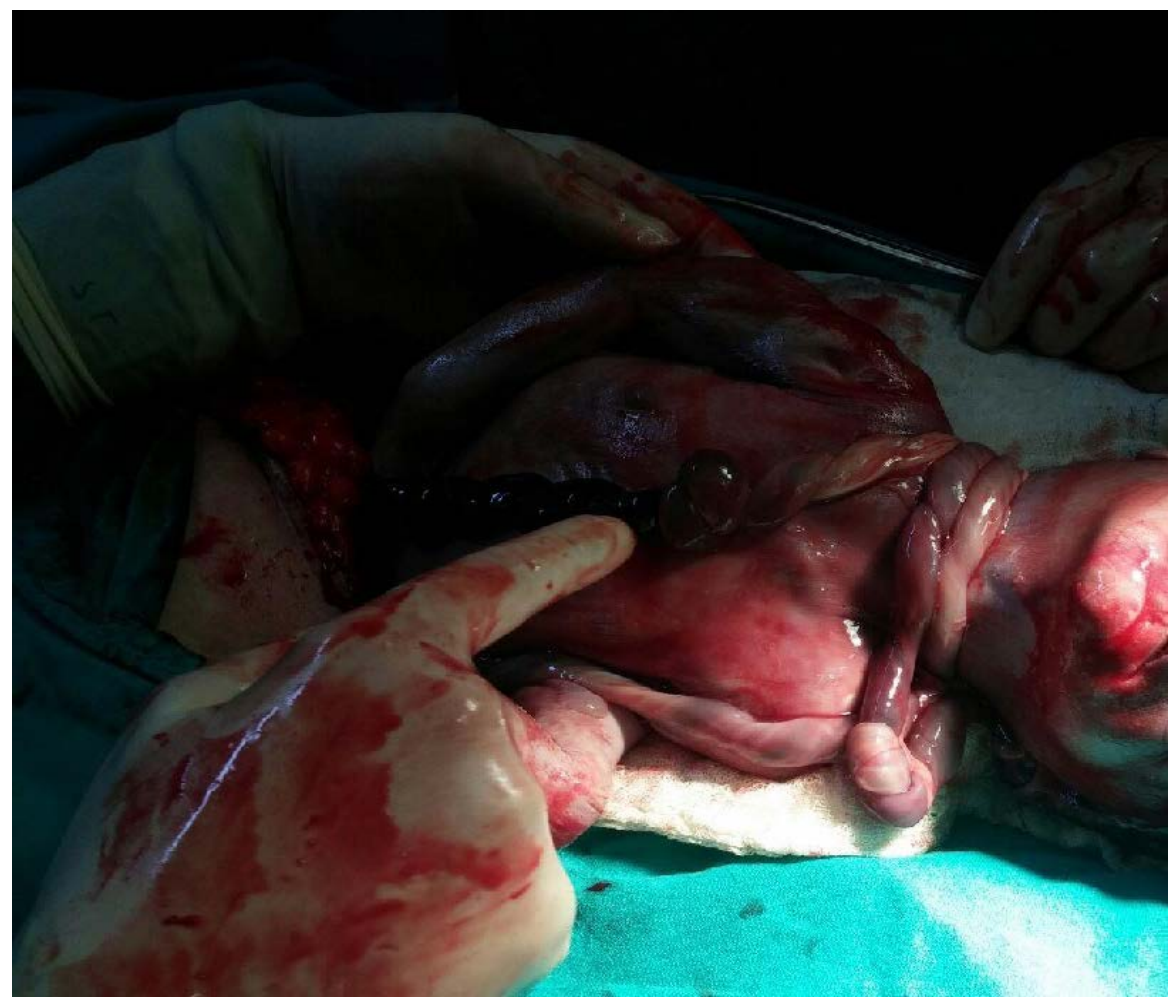

\section{Figure 3}

\section{Conclusion}

The rare antenatal complication of 3 loops of nuchal cord around the fetus's neck and true knots in 2 places causing death make our case interesting. During antenatal examination from the 2nd trimester, evaluation of nuchal cord with ultrasonography and Doppler ultrasonography is clearly important and a warning for pregnancy check-ups and intrapartum management. Clinicians need to pay more attention to clinical signs of prompting umbilical cords and knots during pregnancy, and should make proper management.

The patient described in the case report has given informed consent for the case report and written confirmation.

\section{References}


1. Larson JD, Rayburn WF, Crosby S, Thurnau GR. Multiple nuchal cord entanglements and intrapartum complications. Am J Obstet Gynecol. $1995 \quad$ Oct;173(4):1228-31. http://dx.doi.org/10.1016/00029378(95)91359-9 PubMed PMID: 7485326.

2. Sheiner E, Abramowicz JS, Levy A, Silberstein T, Mazor M, Hershkovitz R. Nuchal cord is not associated with adverse perinatal outcome. Arch Gynecol Obstet. 2006 May;274(2):81-3. http://dx.doi.org/10.1007/s00404-0050110-2 Epub 2005 Dec 23. PubMed PMID: 16374604.

3. Bernad ES, Craina M, Tudor A, Bernad SI. Perinatal outcome associated with nuchal umbilical cord. Clin Exp Obstet Gynecol. 2012;39(4):494-7. PubMed PMID: 23444751.

4. Kumari S, Saxena A, Monga D, Malik A, Kabra M, Kurray RM. Significance of cord problems at birth. Indian Pediatr. 1992 Mar;29(3):301-5. PubMed PMID: 1612670.

5. Singer DB, Macpherson T. Fetal death and the macerated stillborn fetus. In Wigglesworth JS, Singer DB, editors. Textbook of fetal and perinatal pathology. Boston: Blackwell Scientific Publications; 1991. Volume 1, p. 266267.

6. Tepper R, Kidron D, Aviram R, Markovitch O, Hershkovitz R. High incidence of cord entanglement during early pregnancy detected by threedimensional sonography. Am J Perinatol. 2009 May;26(5):379-82. http://dx.doi.org/10.1055/s-00281110090 Epub 2008 Dec 9. PubMed PMID: 19067280.
7. Cho FN, Liu CB, Li JY, Carey JR, Liou WS. Absent fetal movement and brain sparing effect associated with multiple tight nuchal cords. Taiwan J Obstet Gynecol. $2013 \quad$ Sep;52(3):457-9. http://dx.doi.org/10.1016/j.tjog.2013.06.0 09 PubMed PMID: 24075396.

8. Collins $\mathrm{JH}$, Collins $\mathrm{CL}$, Weckwerth $\mathrm{SR}$, De Angelis L. Nuchal cords: timing of prenatal diagnosis and duration. Am J Obstet Gynecol. 1995 Sep;173(3 Pt 1):768. http://dx.doi.org/10.1016/00029378(95)90337-2 PubMed PMID: 7573240 .

9. Morrison I, Olsen J. Weight-specific stillbirths and associated causes of death: an analysis of 765 stillbirths. Am J Obstet Gynecol. 1985 Aug 15;152(8):975-80. http://dx.doi.org/10.1016/00029378(85)90542-3 PubMed PMID: 4025459.

10. Uludag S, Mad Azlı R, Sen C, Ocak V. Boyunda kordon dolanmasının doğum eylemi üzerine etkisi. Pernatoloji Derg. 1994;2:251-4. Turkish

11. Clapp JF 3rd, Stepanchak W, Hashimoto K, Ehrenberg H, Lopez B. The natural history of antenatal nuchal cords. Am J Obstet Gynecol. 2003 Aug;189(2):488-93.

http://dx.doi.org/10.1067/S0002-

9378(03)00371-5 PubMed PMID: 14520223.

12. Oron T, Sheiner E, Shoham-Vardi I, Mazor M, Katz M, Hallak M. Risk factors for antepartum fetal death. J Reprod Med. 2001 Sep;46(9):825-30. PubMed PMID: 11584485.

13. Kobayashi N, Aoki S, Oba MS, Takahashi T, Hirahara F. Effect of Umbilical Cord Entanglement and Position on Pregnancy Outcomes. Obstet Gynecol Int. 2015;2015:342065. http://dx.doi.org/10.1155/2015/342065 Epub 2015 Jul 9. PubMed PMID: 26240566. 
14. Lipitz S, Seidman DS, Gale R, Stevenson DK, Alcalay M, Menczer J, Barkai G. Is fetal growth affected by cord entanglement? J Perinatol. 1993 Sep-Oct;13(5):385-8. PubMed PMID: 8263624.

15. Giacomello F. Ultrasound determination of nuchal cord in breech presentation. Am J Obstet Gynecol. 1988 Aug;159(2):531-2.

http://dx.doi.org/10.1016/S00029378(88)80123-6 PubMed PMID: 3044121.

16. Balkawade NU, Shinde MA. Study of length of umbilical cord and fetal outcome: a study of 1,000 deliveries. J Obstet Gynaecol India. 2012 Oct;62(5):520-5.

http://dx.doi.org/10.1007/s13224-0120194-0 Epub 2012 Oct 3. PubMed PMID: 24082551.

17. Göynümer G, Yayla M. Gebeliğin ikinci trimesterinde boyun çevresinde kordon dolanması sıklığı ve etkileyici faktörler. Perinatoloji Dergisi. 2004;12(2):93-5. Turkish

18. Larson JD, Rayburn WF, Harlan VL. Nuchal cord entanglements and gestational age. Am J Perinatol. 1997 Oct;14(9):555-7.

http://dx.doi.org/10.1055/s-2007-994333

PubMed PMID: 9394166.

19. Qin Y, Wang CC, Lau TK, Rogers MS. Color ultrasonography: a useful technique in the identification of nuchal cord during labor. Ultrasound Obstet Gynecol. $2000 \quad$ May;15(5):413-7. http://dx.doi.org/10.1046/j.14690705.2000.00113.x PubMed PMID: 10976484. 